\title{
BIOLOGY
}


Banking

Basic English Law

Basic Management

Biology

British Politics

Business Communication

Business Microcomputing

Catering Science

Chemistry

COBOL Programming

Commerce

Computer Programming

Computers

Data Processing

Economic and Social History

Economics

Electrical Engineering

Electronics

English Grammar

English Language

English Literature

Financial Accounting

French

French 2
German

Hairdressing

Italian

Keyboarding

Marketing

Mathematics

Modern British History

Modern European History

Modern World History

Nutrition

Office Practice

Pascal Programming

Physics

Practical Writing

Principles of Accounts

Social Welfare

Sociology

Spanish

Spanish 2

Statistics

Statistics with your Microcomputer

Study Skills

Typewriting Skills

Word Processing

\section{OTHER BOOKS BY THE SAME AUTHOR}

*Work Out Biology

*Mastering Nutrition

Multiple Choice Questions in Biology and Human Biology

Complete Catering Science

Complete Hairdressing Science

Experimental Science for Catering and Homecraft Students

Multiple Choice Questions in Food and Nutrition

*Also published by Macmillan 


\section{MASTERING}

\section{BIOLOGY}

SECOND EDITION

O. F. G. KILGOUR

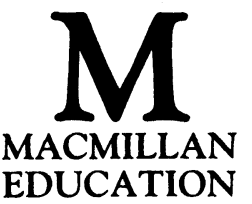


Text (O).F.G. Kilgour 1982, 1987

Figures $@$ Macmillan Education Ltd 1987

All rights reserved. No reproduction, copy or transmission of this publication may be made without written permission.

No paragraph of this publication may be reproduced, copied or transmitted save with written permission or in accordance with the provisions of the Copyright Act 1956 (as amended), or under the terms of any licence permitting limited copying issued by the Copyright Licensing Agency, 33-4 Alfred Place, London WC1E 7DP

Any person who does any unauthorised act in relation to this publication may be liable to criminal prosecution and civil claims for damages.

First edition 1982

Reprinted 1982, 1983, 1984, 1986

Second edition 1987

Published by

MACMILLAN EDUCATION LTD

Houndmills, Basingstoke, Hampshire RG21 2XS

and London

Companies and representatives

throughout the world

British Library Cataloguing in Publication Data

Kilgour, O.F.G.

Mastering biology.--2nd ed.--(Macmillan

master series)

1. Biology

I. Title

$574 \quad$ QH307.2

ISBN 978-0-333-44678-2

ISBN 978-1-349-09692-3 (eBook)

DOI 10.1007/978-1-349-09692-3 
To Irene Rachelle and Janet Katharine 


\section{CONTENTS}

I. CELLULAR ORGANISATION AND DIVERSITY OF LIVING ORGANISMS

1 Introducing biology

2 Diversity of living organisms

3 Cellular organisation of living organisms
1.1 What is biology? 3

1.2 What use is biology? 4

1.3 How biologists work 4

1.4 Biological terms 5

1.5 Biological investigation 5

1.6 Numbers 7

1.7 Biological calculations $\quad 8$

1.8 Graphs 10

1.9 Measurement of length $\quad 13$

1.10 Measurement of area $\quad 13$

1.11 Measurement of volume $\quad 14$

1.12 Measurement of mass/weight 14

1.13 Surface area relationship $\quad 16$

1.14 Questions 18

2.1 Introduction 20

2.2 The species 20

2.3 Naming the organism nomenclature 21

2.4 Classification of organisms 21

2.5 Classification of the plant kingdom 22

2.6 Classification of the animal kingdom 31

2.7 Questions 46

3.1 Characteristics of living

organisms 47

3.2 Microscopes 48

3.3 The cell theory 49

3.4 Cell structure 52

3.5 Unicellular organisms 55 


\section{Biochemical principles}

\section{Biophysical principles}

$\begin{array}{lll} & 4.2 & \text { Chemical compounds } \\ 4.3 & \text { Classifying chemical } \\ & \text { compounds } \\ 4.4 & \text { Mixtures } \\ 4.5 & \text { Water } \\ 4.6 & \text { Acids } \\ 4.7 & \text { Bases } \\ 4.8 & \text { Salts } \\ 4.9 & \text { The pH scale } \\ 4.10 & \text { Chemical reactions } \\ 4.11 & \text { Lipids } \\ 4.12 & \text { Carbohydrates } \\ 4.13 & \text { Proteins } \\ 4.14 & \text { Enzymes } \\ 4.15 & \text { Nucleic acids - } \\ & \text { polynucleotides } \\ & 4.16 & \text { Questions } \\ 5.1 & \text { Movement of molecules } \\ & 5.2 & \text { Solutions } \\ 5.3 & \text { Movement by diffusion } \\ & 5.4 & \text { Permeability } \\ 5.5 & \text { Osmosis } \\ 5.6 & \text { Active transport } \\ & 5.7 & \text { Surface tension and } \\ & \text { capillarity } \\ & 5.8 & \text { Energy } \\ 5.9 & \text { Pressure } \\ 5.10 & \text { Bodies moving in fluids } \\ 5.11 & \text { Heat energy } \\ 5.12 & \text { Light energy } \\ 5.13 & \text { Atomic structure } \\ 5.14 & \text { Questions } \\ & & \end{array}$

3.7 Multicellular organisms and organ systems

3.8 Mammal tissues

3.9 Flowering plant tissues

3.10 Flowering plant organs

3.11 Questions

4.1 Chemical elements

4.2 Chemical compounds

4.15 Nucleic acids -

5.6 Active transport 96

5.7 Surface tension and
capillarity

5.8 Energy 96

5.9 Pressure 98

5.10 Bodies moving in fluids 98

5.11 Heat energy 99

5.12 Light energy 101 


\section{LIFE SUPPORT PROCESSES AND MAINTENANCE}

OF THE INDIVIDUAL

107

6 Plant nutrition

6.1 Nutrition 109

6.2 Photosynthesis

109

6.3 The rate of photosynthesis

6.4 The leaf in photosynthesis

6.5 The biochemical mechanism of photosynthesis

6.6 Questions

7 Animal nutrition

7.1 Types of nutrition

7.2 Physical and chemical food changes

7.3 Heterotrophic nutrition

7.4 Liquid feeders

7.5 Filter feeders

7.6 Large-particle feeders

7.7 Digestion in humans

7.8 Absorption

7.9 The herbivore mammal gut

7.10 Questions

\section{Human diet}

8.1 Food functions

8.2 Food composition

8.3 Energy value of food

8.4 Energy needs

8.5 Carbohydrates in foods

8.6 Lipids in foods

8.7 Proteins in foods

8.8 Ethanol

8.9 Minerals in foods

8.10 Vitamins in foods

8.11 Fibre in foods

8.13 A balanced diet $\quad 167$

8.14 Questions

\section{Transport}

9.1 Introduction

9.2 Principles of transport; transport in simple organisms

9.3 Transport in flowering plants: water absorption 
10 Respiration

\section{Growth}

9.4 Flowering plants: transpiration

9.5 Flowering plants: translocation

9.6 Transport in mammals: mammal blood

9.7 Mammals: blood functions 181

9.8 Mammals: blood vessels $\quad 183$

9.9 Mammals: the heart $\quad 185$

9.10 Mammals: blood circulation 187

9.11 Mammals: exchange of substances at the cells $\quad 189$

9.12 Mammals: lymph and lymphatic system

9.13 Storage in plants and animals

9.14 Questions

10.1 Introduction

10.2 Energy release in living cells 193

10.3 Cell respiration without oxygen 196

10.4 Cell respiration with oxygen 199

10.5 External respiration 203

10.6 External respiration in small animals 205

10.7 External respiration in insects 205

10.8 External respiration in a bony fish 206

10.9 External respiration in humans and mammals 208

10.10 External respiration in flowering plants $\quad 215$

10.11 Questions 218

11.1 Introduction 220

11.2 The cell nucleus 221

11.3 Cell division growth process 223

11.4 Growth process in seeds 226

11.5 Growth process of metamorphosis in animals 229

11.6 Growth regions

11.7 Growth measurement 
11.8 Growth factors

11.9 Growth hormones

11.10 Tropisms - growth movements

11.11 Questions

12 Homeostasis - the

12.1 Principles of homeostasis

steady state

12.2 The liver as a homeostatic organ

12.3 Blood sugar regulation

12.4 Excretion

12.5 Osmoregulation

12.6 Excretion and osmoregulation in animals

12.7 The kidney as a homeostatic organ

12.8 Osmoregulation in plants

12.9 The skin as a homeostatic organ

12.10 Temperature regulation

12.11 Temperature regulation in ectotherms

12.12 Temperature regulation in endotherms

12.13 Homeostatic temperature regulation in endotherm animals

12.14 Questions

13 Irritability

13.1 Stimulus

13.2 Nervous systems

13.3 Receptors

13.4 The human eye

13.5 The insect eye

13.6 The human ear

13.7 Human skin

13.8 Human nose and tongue 287

13.9 Insect sensory organs 288

13.10 Neurones 288

13.11 Nervous coordination - the central nervous system

13.12 The nerve impulse pathways in response

13.13 Chemical coordination 
14 Support and movement

13.14 Homeostasis in the endocrine and nervous systems

13.15 Plant responses

302

13.16 Behaviour 302

13.17 Questions 303

14.1 Physical principles 304

14.2 Hydrostatic skeletons and exoskeletons

14.3 Endoskeletons

14.4 Functions of a mammal skeleton

14.5 Movement in animals

14.6 Skeletal muscle

14.7 Human body support

14.8 Levers in locomotion

321

14.9 Locomotion in water - fish

323

14.10 Locomotion on land

14.11 Locomotion in air - birds and insects

14.12 Support and movement in plants

14.13 Questions

III.DEVELOPMENT OF ORGANISMS AND CONTINUITY OF LIFE 333

\section{Reproduction}

15.1 Introduction 334

15.2 Asexual reproduction

15.3 Vegetative reproduction

15.4 Sexual reproduction 344

15.5 Sexual reproduction in non-seed-bearing plants $\quad 345$

15.6 Sexual reproduction in seed-bearing plants

15.7 Pollination

15.8 Fertilisation

15.10 Sexual reproduction in invertebrate animals

15.11 Sexual reproduction in vertebrate animals

15.12 Sexual reproduction in mammals 
15.13 The human reproductive system 359

15.14 Fertilisation 363

15.15 Birth control 364

15.16 Development and pregnancy 365

15.17 Birth 366

15.18 Parental care $\quad 367$

16 Genetics

15.19 Questions 368

16.1 Introduction 369

16.2 Phenotype 369

16.3 Genetic material - the chromosomes $\quad 370$

16.4 Genetic material - the

16.5 Meiosis 376

16.6 Nuclear division in the life-cycle $\quad 378$

16.7 Principles of inheritance $\quad 379$

16.8 The back or test cross 384

16.9 Incomplete dominance or codominance

16.10 Inheritance of human blood groups $\quad 388$

16.11 Sex linkage $\quad 390$

16.12 Human heredity 392

16.13 Non-heritable variation 393

16.14 Heritable variation $\quad 396$

16.15 Questions 399

17 Evolution

17.1 Introduction 400

17.2 Chemical evolution $\quad 400$

17.3 Evidence for organic evolution 401

17.4 Theories of evolution $\quad 406$

17.5 Genetics and evolution 407

17.6 Gene pool 408

17.7 Factors affecting the gene pool $\quad 408$

17.8 Sickle cell anaemia $\quad 409$

17.9 Natural selection in action 410

17.10 New species formation $\quad 412$

17.11 Questions 413 


\section{INTER-RELATIONSHIPS BETWEEN ORGANISMS} AND THE ENVIRONMENT

18 Ecology

19 Humans and micro-organisms

20 Human influences in the ecosystem

Reading list

$\begin{array}{cl}\text { 18.1 } & \text { Introduction } \\ 18.2 & \text { Ecology } \\ 18.3 & \text { Identification of the speci } \\ 18.4 & \text { Investigating a natural } \\ & \text { habitat } \\ 18.5 & \text { Soil } \\ 18.6 & \text { Soil as a habitat } \\ \text { 18.7 } & \text { Interrelations between } \\ & \text { organisms }\end{array}$

18.8 Processes in the ecosystem

18.9 Energy flow in the ecosystem

18.10 Cycling of chemical - elements in the ecosystem

18.11 Questions

19.1 Disease

19.2 Warning: working with micro-organisms

19.3 Bacteria

19.4 Viruses

19.5 Fungi

19.6 Protozoa

19.7 Body defences against pathogens

19.8 Biotechnology

19.9 Questions

20.1 Human population

20.2 The human population explosion

20.3 Humans and agriculture

20.4 Pests

20.5 Humans and earth resources

20.6 Humans and earth pollution

20.7 Humans and earth conservation 20.8 Questions
417

417

418

418

421

426

428

434

439

440

444

445

445

446

454

457

461

464

467

467

468

471

476

478

482

483

489

491

493

495

495

516 


\section{PREFACE TO THE}

\section{FIRST EDITION}

The aim of this book is to emphasise the importance of understanding the principles of biology rather than to be a separate study of plant and animal types. The approach includes an elementary treatment of the chemistry, physics and mathematics essential to a proper understanding of biological processes. For additional exercises in answering questions, the reader is referred to the author's Multiple Choice Questions in Biology and Human Biology published by Heinemann Educational Books.

I should like to express my sincere thanks to Meinwen Parry, B.Sc., M.I.Biol., a biology teacher of long experience, for her critical reading of the typescript and many invaluable suggestions to improve the work, and to my son David Kilgour of New Zealand for his help and advice.

I am indebted to Dr Ronald Hope, Director of the Marine Society, for use of reference facilities, and for my correspondence tutoring experience with the Seafarers Education Service, which provided the insight to the specific needs of a student working alone by self-education.

I thank the industrial and international organisations named in the figure, plate or table captions for permission to use photographic and reference material, and also William Heinemann Medical Books Ltd for permission to re-use certain illustrational material that appeared in the author's An Introduction to The Biological Aspects of Nursing Science.

Finally, thanks are due to Mrs V. C. Stirling for her faultless work in preparing the typescript.

The illustration of a white blood cell engulfing a bacterium which appears on the front of the dust jacket and cover was photographed with phase contrast by Gene Cox of Trowbridge and the publishers are grateful for permission to use it here.

O. F.G.K. 


\section{PREFACE TO THE}

\section{SECOND EDITION}

In this second edition the text is divided into the four main themes to conform to the Secondary Examinations Council, National Criteria in Biology. New material is also included to meet the subject content requirements of the different Examining Groups General Certificate of Secondary Education - GCSE - syllabuses in Biology.

The reader is strongly advised to use the author's companion titles Work Out Biology GCSE and Multiple Choice Questions in Biology and Human Biology in order to gain familiarity with the different types of examination question they will encounter in the GCSE, apart from the free response and data interpretation questions given in this book.

Practical assessment either school based or by an alternative external examination is an important aspect of biology study covered in this text in outline practical procedures and by emphasis on basic practical skills in Work Out Biology GCSE.

I renew my appreciation to the Marine Society in obtaining all the GCSE syllabuses for the 1988 examination for me, and thank Mary Waltham and Peter Oates of Macmillan Education for their kind assistance and encouragement.

I value the help and interest shown by the New Zealand School Certificate Board and West Australia Secondary Examinations Authority.

Colwyn Bay, Wales - Cymru

O.F.G.K. 